\title{
PATH ANALYSIS OF FACTORS AFFECTING BULLYING BEHAVIOR IN SCHOOL AGE CHILDREN IN SMPN 1 RAMBIPUJI JEMBER
}

\author{
Resti Utami \\ Faculty of Health Science, University of Muhammadiyah Jember \\ Corresponding email : resti.utami@unmuhjember.ac.id
}

\begin{abstract}
BACKGROUND : Bullying that is often found in school-age children can have an impact both physically and psychologically on the lives of children in school and the stages of child development. The impact of bullying for children can last a lifetime, both for victims and bullying perpetrators themselves. Many factors contribute to the emergence of bullying behavior in the school environment. However, these factors were never identified by the school to determine the appropriate intervention in overcoming the problem of bullying in children at school. Nurses can act as early case finding through activities to identify factors that can influence the emergence of bullying in schools to be able to determine the handling and prevention of bullying behavior in schools. The purpose of this study was to analyze the factors that influence bullying behavior in school-age children.

SUBJECT AND METHODE :The design of this study used the explanatory research design of the cross-sectional survey with a sample of 74 respondents.

RESULTS : The results showed that (1) biopsychological factors had a significant effect on bullying behavior; (2) cognitive factors had a significant influence on bullying behavior; (3) social factors had a significant effect on bullying behavior.

DISCUSSION : Pathway analysis of factors affecting bullying by considering biopsychological, cognitive and social factors is adequate for nurses to predict in identifying the causes of bullying behavior in school-age children.
\end{abstract}

Keywords: bullying, children, school-age

\section{INTRODUCTION}

The last few years bulllying has become a serious threat to the development of children and causes of violence on childern. Bullying is any proactive aggressive behavior that is characterized by an imbalance of power between the offender and the victim which usually involves repetition (Erhabor, 2013; Odar Stough et al., 2016; Zakiyah, Humaedi and Santoso, 2017). Bullying that occurs in schools has three integrated characteristic, including (1) actions that are intentionally carried out by the perpertrators to hurt victims, (2) actions taken unbalanced so as to create a sense of pressure on the victim, and (3) action taken repeatedly (Sufriani and Sari, 2017). The phenomenon of bullying is a world problem that can have a negative impact on a lifetime for perpetrators of bullying, victims of bullying and people around it (Polanin, Espelage and Pigott, 2012).

The impact of bullying in childhood can last for a lifetime, both for the victims and pepetrators it self. However the perpetrators of bullying are found to be healthier compared to victims of bullying (Sufriani and Sari, 2017). The case of bullying in Indonesia can occur at all levels of schools including elementary school, secondary schools to tertiary institutions. The Indonesian Child Protection (KPAl) in 2014 noted that of the total complaints of bullying, which occured in the education sector as many as 1,480 cases. KPAl found that children experienced bullying in the school environment by $87.6 \%$ with details : $29.9 \%$ bullying was done by teachers, $42.1 \%$ was carried out by classmates, and $28.0 \%$ 
was carried out by other classmate (Putri, 2015). This shows that the prevalence of bullying behavior is still high in the school environment.

Priyatna (2010) suggest there is no single cause of bullying. Many factors contribute to bullying behavior in the school environment. Individual factors, cognitive, social, environmental risk, protection also determine the etiology of bullying behavior, where this can affect the growth and development of children according to age stages (Sufriani and Sari, 2017).

Nursing as an integral part of health services plays an important role in providing nursing services, including in schools through the management of School Health Efforts (UKS) in order to ensure ths students can grow and develop according to tha age stages. In line with the purpose of UKS, nurses can act as an early case finding through identifying the causes of bullying in schools to be able to determine the handling and efforts to prevent bullying behavior bay cinducting research on the path analysis of factors affecting bullying behavior in school age children.

\section{METHODE}

The design of this study used an explanatory research design survey cross sectional approach. The study was conducted at SMP1 Rambipuji Jember. The time of study was carried out in April 2019. The focus of ths study was conducted at the SMP 1 Rambipuji in the age range of 12 - 15 years old. This phase is classifies as early adolescents, where students are undergoing a transition period when children are no longer suitable to be treated as small children, but their physical and mental growth is not yet feasible to be considered an adult. In this phase adolescent experience a periode of strom and stress, whe unstabel emotional upheaval is accompanied by rapid physical growth and psychological development that is very susceptible to environmental influences. The sample size after calculation using Slovin formula is at least 74 respondents. In the process, this research through ethical clearance firstly refer to the National Health Research and Developmen Ethics Commision (KEPPN, 2017) namely respect for persons, beneficinece and maleficience and justice. The instrument used in this study is a questionnaire. Data were analyzed using Partial Least Square (PLS)..

\section{RESULT AND DISCUSSION}

A. Result of Descriptive Study

Table 1. Distribution Frequency Respondents Characteristics

\begin{tabular}{|c|c|c|}
\hline Variable & Frequency & Percentage (\%) \\
\hline \multicolumn{3}{|l|}{ a. Gender } \\
\hline 1) Male & 33 & 44,6 \\
\hline 2) Female & 41 & 55,4 \\
\hline Total & 74 & 100,0 \\
\hline \multicolumn{3}{|l|}{ b. Age (years old) } \\
\hline 1) 12 & 11 & 14,9 \\
\hline 2) 13 & 57 & 77,0 \\
\hline 3) 14 & 6 & 8,1 \\
\hline
\end{tabular}




\begin{tabular}{|c|c|c|}
\hline Variable & Frequency & Percentage (\%) \\
\hline Total & 74 & 100,0 \\
\hline \multicolumn{3}{|l|}{ c. Personality } \\
\hline 1) Introvert & 28 & 37,8 \\
\hline 2) Ekstrovert & 46 & 62,2 \\
\hline Total & 74 & 100,0 \\
\hline \multicolumn{3}{|l|}{ d. Knowledge } \\
\hline 1) $\mathrm{Bad}$ & 32 & 43,2 \\
\hline 2) good & 42 & 56,8 \\
\hline Total & 74 & 100,0 \\
\hline \multicolumn{3}{|l|}{ e. Peer support } \\
\hline 1) $\mathrm{Bad}$ & 26 & 35,1 \\
\hline 2) Good & 48 & 64,9 \\
\hline Total & 74 & 100,0 \\
\hline
\end{tabular}

According to the data in table 1 we see that $55,4 \%$ respondents are female; $77 \%$ are 13 years old; $62,2 \%$ are extrovert; $56.8 \%$ respondents has good knowledge; $64.9 \%$ repondents has good peer support.

Table 2.Distribution Frequency of Bullying Behavior in SMPN 1 Rambipuji

\begin{tabular}{|c|c|c|}
\hline Variabel & Frequency & Persentase (\%) \\
\hline \multicolumn{3}{|l|}{ Bullying behavior } \\
\hline 1) Low & 28 & 37,8 \\
\hline 2) Medium & 25 & 33,8 \\
\hline 3) High & 21 & 28,4 \\
\hline Total & 74 & 100,0 \\
\hline
\end{tabular}

According to the data on table 2 show that $37.8 \%$ respondents show low bullying behavior.

B. Result Study of Interferensial Analysis

1. Hipothesis testing

a. Measurement testing ( outter) model

1) Convergent validity

On this study the convergent validity value are shown in the picture below

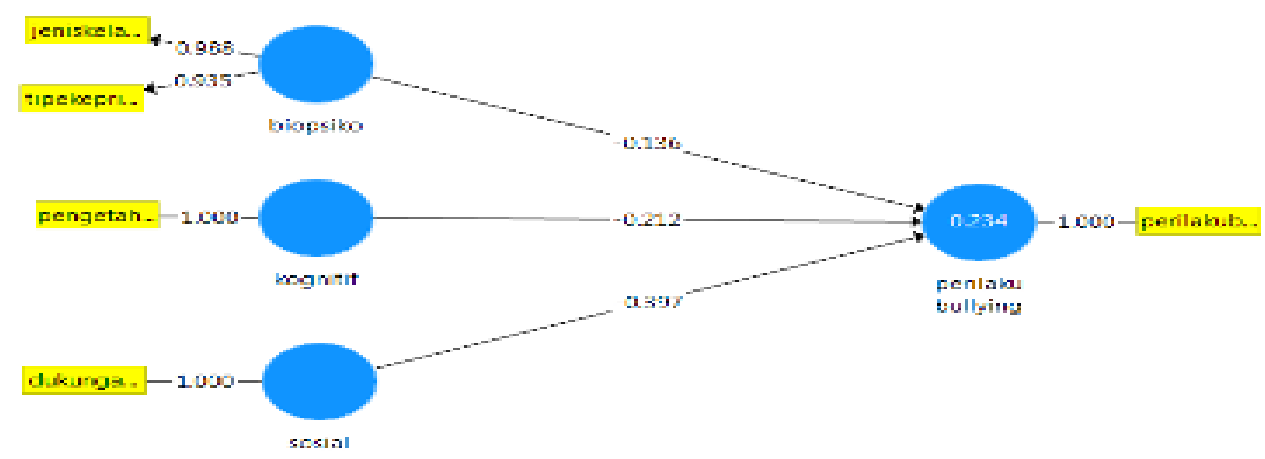

Picture 1. Path analysis and end outer loading value

Outer loading value for all indicators both from indicator for laten variables such as biopsyco, cognitif and social factors that can be seen in this table below : 
Table 3. convergent validiy result

\begin{tabular}{lllcc}
\hline No. & Variable & Indicator & $\begin{array}{c}\text { Outer } \\
\text { Loading }\end{array}$ & Information \\
\hline 1. & Bipsyco factor & X1.1 gender & 0.988 & Valid \\
& & X1.2 personality & 0,935 & Valid \\
\hline 2. & Cognitive factor & X2.1 knowledge & 1,000 & Valid \\
\hline 3. & Social factor & X4.1 peer support & 1,000 & Valid \\
\hline \multicolumn{4}{l}{ According to the data in table 3 we see that all indicators on the structure has met }
\end{tabular}

the validity test

2) Reliability test

Table 4. Result (AVE) composite reliability, cronbachs alpa show $>0.7$ so that it can be conclude that all laten variables (biopsycho, kognitif and social factors) has met the reliability test. The next test is convegent validiity is average variance extracted value (AVE). The AVE value above 0.5 is recommended. According to table 4 , the AVE value for all laten variables are above 0.5 .

b. Structural model testing (inner)

Table 5. Hipotesis Testing Result

\begin{tabular}{l|l|c|c|c}
\hline No. & \multicolumn{1}{|c|}{ variable } & $\begin{array}{c}\text { Sample } \\
\text { origin } \\
(\mathbf{0})\end{array}$ & T statistic & Innformation \\
\hline 1. & $\begin{array}{l}\text { The affect of biopsyco factor to bullying } \\
\text { behavior }\end{array}$ & $-0,136$ & 0,927 & No effect \\
\hline 2. & $\begin{array}{l}\text { The affect of kognitif factor to bullying } \\
\text { behavior }\end{array}$ & $-0,212$ & 1,644 & No effect \\
\hline 3. & $\begin{array}{l}\text { The affect of social factor to bullying } \\
\text { behavior }\end{array}$ & $-0,397$ & 3,688 & Affecting \\
\hline
\end{tabular}

According to the data in table 5 , ot show that biopsyco (T statistic $2.351>2.0$ ) mean that social factors has singnificant effect to bullying behavior. But according to table 5 , the association of biopsyco and cognitif factors to bullying behavior are explained as follow:

Table 6. cross tabulation of social and cognitif factirs to bullying behavior

\begin{tabular}{|c|c|c|c|c|c|c|c|c|c|c|}
\hline \multirow[t]{3}{*}{ Biophysical } & \multirow[t]{3}{*}{ Cathegory } & \multicolumn{6}{|c|}{ Bullying behavior } & \multicolumn{2}{|c|}{ Total } & \multirow[t]{3}{*}{ P Value } \\
\hline & & \multicolumn{2}{|c|}{ High } & \multicolumn{2}{|c|}{ Moderate } & \multicolumn{2}{|c|}{ Low } & \multirow[t]{2}{*}{$\mathbf{N}$} & \multirow[t]{2}{*}{$\%$} & \\
\hline & & $\mathbf{F}$ & $\%$ & $\mathbf{F}$ & $\%$ & $\mathbf{F}$ & $\%$ & & & \\
\hline \multirow[t]{2}{*}{ Gender } & Male & 9 & 27,3 & 4 & 12,1 & 20 & 60,6 & 33 & 44,6 & 0,000 \\
\hline & Female & 12 & 29,3 & 21 & 51,2 & 8 & 19,5 & 41 & 55,4 & \\
\hline \multirow[t]{2}{*}{ Personality } & Introvert & 9 & 32,1 & 4 & 14,3 & 15 & 53,6 & 28 & 37,8 & 0,016 \\
\hline & Ekstrovert & 12 & 26,1 & 21 & 45,7 & 13 & 28,3 & 46 & 62,2 & \\
\hline \multirow[t]{3}{*}{ Cognitive } & Cathegory & \multicolumn{6}{|c|}{ Bullying behavior } & \multicolumn{2}{|c|}{ total } & P Value \\
\hline & & \multicolumn{2}{|c|}{ High } & \multicolumn{2}{|c|}{ Moderate } & \multicolumn{2}{|c|}{ Low } & \multirow[t]{2}{*}{$\mathbf{N}$} & \multirow[t]{2}{*}{$\%$} & \\
\hline & & $\mathbf{F}$ & $\%$ & $\mathbf{F}$ & $\%$ & $\mathbf{F}$ & $\%$ & & & \\
\hline \multirow[t]{2}{*}{ Knowledge } & Good & 11 & 26,2 & 8 & 19,0 & 23 & 54,8 & 42 & 56,8 & 0,001 \\
\hline & Bad & 10 & 31,3 & 17 & 53,1 & 5 & 15,6 & 32 & 53,2 & \\
\hline
\end{tabular}


The result of data analysis using chi square test association tabulation biophysical factors (gender and personality) to bullying behavior on the table 6 we could see that $p$ value is 0.000 and 0.0016 with significancy value 0.05 and association tabulation cognitive factors (knowledge level) to the bullying factors can be seen that $p$ value 0.001 with signficancy value 0.05 . $P$ value is smaller than significance level, so the $\mathrm{HO}$ is rejected. It mean there are significant correlationshio between biophysical and cognitive factors to bullying behavior in school age children at SMPN 1 Rambipuji. So we can clonclude that biophysical and cognitive factors has significant effect to bullying behavior of school age children.

C. Biophysical factors to bullying behavior

Biophysical factor analysis (gender and personality) is has no significant effect to bullying behavior at school age children. But according to analyisis using chi square test the association of biophysical factors (gender and personality) to bullyng behavior shows significant correlationship with negative influence direction (original sample $-0,136$ ) wich is female respondent with extrovert personality tend to be low in bullying behavior.

This results is supported by the study of Erhabor (2013) which show that boys commit more aggression and intimidation than girls. Male violent behavior tends to be open and does not hesitate to use physical violence. On the contrary, that women tend not to do violence directly and more often to use violence that is closed and difficult to observe (Reed and Submitted, 2007). However, bullying can be found in both boys and girls, but its intensity is influenced by the received socialization porccess. This shows that male gender contributes a lot to bullying behavior.

Personality of bullying behaviors been reported as one of factors that could predict problems of bullying behavior in school age children (Erhabor, 2013). Bullying behavior are affected by individual personality types and tend to happen at teenage boys with extrovert personality (Utomo, 2013). But this study results is showing that the extrovert personality is tend to be low in practicing the bullying behavior. And it is affected by other facors in personality type according to Eysenck (1970: Erhabor. 2013); extrovert and introvert factors are be equipped by others factor such as psycotochism (Eysenck, 1970). The natureof this psychotic factors can be conveyed briefly whisch is characterized (ie, has a high burden): (1) solitary, not caring for others, (2) partial difficulties; (3) cruel; inhumane, (4) Lack of feelings; not sensitive, (5) sensation seeking "arousal jag", (6) hostile to others; (9) fooling others. According to Eysenck there is close relationship between psychosis (especially schizophrenia) and crime or that psychosis has certain important characteristics with crime. In addition, this also influenced by others factors suc as parenting style, where according to the results of research by Sewanna Conner Buchanan (2013) , an active child who is not supervised byparents and shy children, timid with hard discipline shows a high level of agression. Thus, extrovert personality types which can be influenced by other factors namely psychoticism and parenting patterns.

D. Cognitive behavior to bullying behavior

Cognitive factors analyisis is not siginificantly affected the bullying behavior in school age children. Cognitive factors (knowledge) is affected bullying behavior in school age children. But according to chi aquare test the association if cognitive factor (knowledge) to bullying behavior shows significant correlation with negative influence direction (original sample -0.212) mean that the lower the knowledge the lower bullying behavior. So the cognitive behavior is 
significantly affected the bullying behavior. This results is supported by the study conducted by Nurfadli(2012) which shows almost half of $(48.3 \%)$ which is 42 responndents has good knowledge about bullying has low bullying behavior where the better knowldege of the teenangers it will minimize or get rid of bullying behavior.

E. Social factors to bullying behavior

Analysis socail factors is significantly effected bullying behavior at school age children. Social factors (peer group support) is affected bullyung behavior in school age children with negatif influence direction (original sample -0.397). mean that the better peer group support the bullying behavior tend to minimize. It shows that the role of their peer to do negatve ghing is alsmost not exist (Annisa'i Rohimah, 2016). Peer group, teacher, and school environment and uphold religious values are very important in shaping the character of the students. This is contrary to the research from Nathania and Godwin (2012) that the existence of peers has a negative influence by spreading the idea (both actively and passively) that bullying is not a big problem and is a natural thing to do.

\section{CONCLUSION AND RECOMMENDATION}

According to the result of study, it can be conclude that :

1. Female tend to bel low in bullying behavior

2. Extrovert personality is tend to be low in doing bullying behavior if compared with intovert behavior which affected by others factor such as psychotisme and parenting type

3. The higher knwoldege the bullying behavior ted to be low

4. The better support from peer support the bullying behavior tend to be low

The next study are expected to do further study that can be developed on bullying victims such as the impact of bullying on children's growth and development

\section{REFERENCE \\ Annisa'i Rohimah (2016) HUBUNGAN PERAN KELOMPOK TEMAN SEBAYA DENGAN PERILAKU BULLYING PADA ANAK USIA SEKOLAH DI SD MUHAMMADIYAH MLANGI GAMPING SLEMAN YOGYAKARTA. Yogyakarta. Available at: http://digilib.unisayogya.ac.id/2028/1/NASKAH PUBLIKASI 2.pdf (Accessed: 7 August 2019).}

Erhabor, S. I. (2013) 'EPQ and self-esteem scores of male and female bullies in Mafikeng schools, South Africa', Gender and Behaviour, 11(1), pp. 5208-5219.

KEPPN (2017) 'PEDOMAN DAN STANDAR ETIK PENELITIAN DAN PENGEMBANGAN KESEHATAN NASIONAL'. Available at: http://keppkn.kemkes.go.id/.

Masdin (2013) 'Fenomena Bullying Dalam Pendidikan', Jurnal Al-Ta'dib, 6(2), pp. 73-83. doi: http://dx.doi.org/10.1007/s00339-010-6034-0.

Nathania, L. and and Godwin, R. (2012) 'NASIONAL PADA SISWA KELAS XII SMA X DI JAKARTA', p. 97.

Nurfadli, A. (2012) 'Hubungan Tingkat Pengetahuan Tentang Bullying dengan Perilaku Bullying Pada Remaja'. Available at: http://digilib.unusa.ac.id/data_pustaka-7823.html. 
Odar Stough, C. et al. (2016) 'Prevalence and Predictors of Bullying Behavior among Overweight and Obese Youth in a Nationally Representative Sample', Childhood Obesity, 12(4), pp. 263271. doi: 10.1089/chi.2015.0172.

Polanin, J., Espelage, D. and Pigott, T. (2012) 'A Meta-Analysis of School-Based Bullying Prevention Programs' Effects on Bystander Intervention Behavior', School Psychology Review, 41(1), pp. 47-65. doi: 10.1128/AAC.00466-11.

Putri, H. N. (2015) 'FAKTOR-FAKTOR YANG BERHUBUNGAN DENGAN PERILAKU BULLYING PADA REMAJA', 2(2).

Reed, A. L. and Submitted (2007) " I WON " T THINK ABOUT IT THE SAME WAY AGAIN": CRITICAL LITERACY AS AN ANTI-BULLYING TOOL IN THE MIDDLE SCHOOL SETTING Amber $L$. Reed Submitted to the faculty of the University Graduate School In partial fulfillment of the requirements of the degree Doc', (August).

Shewanna Conner Buchanan (2013) DEVELOPING A FRAMEWORK FOR IDENTIFYING THE CHARACTERISTICS OF THE BULLY AND THE BULLIED IN MIDDLE SCHOOLS : A PILOT STUDY A Dissertation Submitted to the Graduate School of Tennessee State University in Partial Fulfillment of the Requirements for the Degr.

Sufriani, S. and Sari, E. P. (2017) 'Faktor yang Mempengaruhi Bullying pada Anak Usia Sekolah di Sekolah Dasar Kecamatan Syiah Kuala Banda Aceh', Idea Nursing Journal, 8(3).

Yusmansyah, S. L. and Mayasari, S. (2018) 'Bentuk dan Faktor Penyebab Perilaku Bullying Forms and Factors Causing Bullying Behavior', (1).

Zakiyah, E. Z., Humaedi, S. and Santoso, M. B. (2017) 'Faktor Yang Mempengaruhi Remaja Dalam Melakukan Bullying', 4(2), pp. 129-389. Available at: http://repository.usu.ac.id. 